\title{
REFORMED CONFESSIONS AND SCHOLASTICISM. DIVERSITY AND HARMONY
}

\author{
ANDREAS J. BECK \\ Evangelical Theological Faculty, Leuven
}

\begin{abstract}
This paper discusses the complex relationship of Reformed confessions and Reformed orthodox scholasticism. It is argued that Reformed confessions differ in genre and method from Reformed scholastic works, although such differences between confessional and scholastic language should not be mistaken for representing different doctrines that are no longer in harmony with each other. What is more, it is precisely the scholastic background and training of the authors of such confessions that enabled them to place their confessional writings in the broader catholic tradition of the Christian church and to include patristic and medieval theological insights. Thus proper attention to their scholastic background helps to see that at least in some confessions the doctrine of predestination, for instance, is not as 'rigid' as one might think at first sight. In order to demonstrate that the doctrine of the Reformed confessions was much in line with the scholastic theology of Reformed orthodoxy, this paper discusses, after having explained the terms 'Reformed orthodoxy' and 'scholasticism', the early Reformed scholastic theologians Beza, Zanchi, and Ursinus, who also have written confessional texts. The paper also includes a more detailed discussion of the Belgic Confession and the scholastic background of the Canons of Dordt and the Westminster Confession, thereby focusing on the doctrines of God, providence, and predestination.
\end{abstract}

KEY WORDS: Reformed confessions, scholasticism, Belgic Confession, Synod of Dordt, predestination

\section{Introduction}

Around 1565, we observe not only the rise of most national Reformed confessions, but also the beginning of Reformed orthodoxy and scholasticism. At the start of what is now called, in socio-political and cultural research, the process of 'confessionalization' (Schilling 1986; Ehrenpreis and Lotz-Heumann 2002), there was an increasing need for the education of elites within the different confessions (Selderhuis and Wriedt 2006). This coincidence alone might suggest that Reformed confessions and scholasticism are not necessarily opposed to each other. Yet 'scholasticism' generally has the reputation of being 'speculative', 'metaphysical', 'arid', 'dry', 'rigid', or 'dead', often

* ANDREAS J. BECK (PhD 2007, Utrecht University) is professor of historical theology as well as academic dean at the Evangelical Theological Faculty, Leuven, Belgium. Email: andreas.beck@etf.edu. 
even among those theologians and researchers who would ascribe, at least to some Reformed confessions, attributes as 'vitality', 'warm-heartedness', and 'deep spirituality'. Also, with many the Reformed confessions have the reputation of being, as a result of their pastoral tone, more 'soft' on doctrinal issues than the allegedly stern and stringent scholastic treatises of the Reformed orthodox.

In this paper I will analyse the relationship between Reformed confessions and Reformed orthodox scholasticism. In a first step, we will explain the terms 'Reformed orthodoxy' and 'scholasticism'. Second, we will briefly look at three early proponents of Reformed scholasticism who also have writtenconfessional texts (Beza, Zanchi, and Ursinus). Is there a difference in content between their various writings? In examining this, we will focus on the doctrines of God, providence and predestination, although some broader soteriological issues will also be addressed. This will also be the focus, thirdly, of a more detailed discussion of the Belgic Confession. Forth, we will briefly explore the scholastic background of the Canons of Dordt and the Westminster Confession. The final section offers some concluding remarks.

\section{Reformed Orthodoxy and Scholasticism}

Being a compound of the Greek terms 'orthos' and 'doxa', 'orthodoxy' originally means 'right opinion' or 'right teaching', referring to a particular content, which must be defended in the face of dissent. Taken this way, the term 'Reformed orthodoxy' would be used to refer to a specific denominational doctrine of the Reformed churches in general terms. However, 'Reformed orthodoxy' can also be used as an epochal term to denote a certain age, namely the period in the history of Reformed Protestantism after the early Reformation in Early Modernity (Muller 2003b; van Asselt 2013).

The starting point (or terminus a quo) of Reformed orthodoxy is generally placed around the year 1565, when a large part of the national Reformed confessions had emerged, including the French Confession or Confessio Gallicana (1559), the Scottish Confession (1560), the Belgic Confession or Confessio Belgica (1561), and the Second Helvetic Confession (1566). The Heidelberg Catechism (1563), largely written by a pupil of Melanchthon, Zacharias Ursinus (1534-1583), falls in this period as well. This is also the period after the demise of many reformers of the second generation, as Philip Melanchthon $(\dagger$ 1560), Johannes a Lasco $(\dagger 1560)$, Peter Martyr Vermigili († 1562), Wolfgang Musculus ( $†$ 1563), John Calvin ( $†$ 1564), Andreas Hyperius $(\dagger 1564)$, and Guillaume Farel († 1565).

The end of the epoch (or terminus ad quem) is less clearly determined; historians oscillate between 1725 and 1775 . This reminds us of the fact that periodization is generally the activity of historians who divide history into different epochs, and not a feature of history itself. To be sure, there has been 
an important shift between the eighteenth and the beginning of the nineteenth century, especially around the conquests of Napoleon, after which at many universities the expertise of reading Latin scholastic texts became lost.

With Richard Muller, we can further divide the epoch of Reformed orthodoxy into three phases: early Orthodoxy (about 1565-1640), high Orthodoxy (about 1640-ca. 1725) and late Orthodoxy (about 1725-1770). Both early and high Orthodoxy can be in turn divided into two sub-phases. In case of early Orthodoxy, the demarcation line between both sub-phases can be seen in the Synod of Dordt in 1618-19, and in case of high Orthodoxy, the demarcation line between both sub-phases can be seen in the death of Gisbertus Voetius in 1676 and of François Turrettini in 1687 (Muller 2003a: 311).

It should be noted that the terms 'orthodoxy' and 'scholasticism' are not interchangeable. While the term 'orthodoxy' is mainly used as an epochal term, 'scholasticism' refers primarily to a scientific practice or method (Muller 2003a: 25-46; van Asselt 2011). Here it is useful to remember its etymological derivation from the Latin word schola ('school'). To cite the medievalist Lambertus M. de Rijk, 'scholasticism' is

a collective term for all scientific activity, especially theological and philosophical, which follows a specific method. This method is characterised, both on the level of research and on the level of teaching, by the use of a constantly recurring system of concepts, distinctions, definitions, propositional analyses, argumentational techniques, and disputational methods (de Rijk 1985: 20-1, my translation; cf. ibid., 82-105).

Scholasticism pertains to a set of instruments to which students were introduced early on in their education (i.e. already at the artes-faculty) from the time of the establishment of the universities ca. 1200 down into the eighteenth century. This method was also applied in the Protestant universities and academies, although there have been significant modifications largely due to Renaissance humanism (Vos 2013; cf. Perreiah 2014). Thus the Sitz im Leben, the historical and cultural context of 'scholasticism', is the medieval or early modern university or academy. The common use of the scholastic method by Catholic, Lutheran, and Reformed scholars may at first glance give the impression of doctrinal unity. However, recent investigations have unveiled a high diversity of detail and insights, even within Reformed scholasticism itself. The Reformed orthodox systems did not form a monolithic bloc, even if they fitted within confessional borders, which, more than in the Lutheran tradition, varied somewhat in different regions and times. Moreover, important Reformers such as Martin Bucer (born 1491), Wolfgang Musculus (born 1497), Peter Martyr Vermigli (born 1499), and John Calvin (born 1509), all of whom had been influenced by both medieval scholasticism and 
Renaissance humanism to some extent, differed in many respects. The Reformed tradition does not have a counterpart to the Lutheran Book of Concord; as Ursinus emphasised in his reaction to the Book of Concord, the Reformed assigned higher authority to the catholic public writings, i.e. the Apostles' and Nicene creeds and the Symbolum Quicumque, than to their own particular writings, i.e. the Reformed confessions (Ursinus 1612: 2:540-3). For all these reasons, the term 'Calvinism' is quite misleading and the socalled 'Calvin against the Calvinists' debate seems to be largely obsolete (Muller 2011; cf. Beck 2016).

The Reformed theologians themselves reflected on the meaning of 'scholasticism'. Thus, as early as 1546 the Marburg theologian Andreas Hyperius (1511-1564) started to develop the distinction between a 'scholastic' treatment of theology in the university setting and a 'popular' treatment of theology in preaching and popular writing (Sinnema 1999). In more detail, the Dutch Utrecht theologian Gisbertus Voetius (1589-1676) addressed the issue of 'scholasticism' in his disputation De theologia scholastica (1640) (1648: 1229). He also understands scholasticism as a method: in a wider sense 'scholasticism' means the 'form and method of theology which are current in European schools', and its name is derived from the fact that 'it is handed down in the schools, and that its essence and method (ratio ac methodus) are different from the theology which is proclaimed in the churches' (1648: 13). In the strict sense of the word, 'scholasticism' is to be understood as

that form and method of theology which can first be found synoptically in the four books of [Lombard's] Sentences, and which Thomas Aquinas after him set forth in the three parts of his Summa theologiae. To these should next be added all commentators of the Sententiae with their disputations and commentaries on Lombard, and the later scholastics with their commentaries on Thomas. Finally, to them also belong all authors of anthologies and quodlibeta who devised further quaestiones and quodlibeta (Voetius 1648: 13-4).

Voetius immediately goes on to add, however, that the scholastic theology he supports, or 'the scholastic, that is, the didactic and apologetical (elencticus) professor of theology', is far (toto coelo) removed from the scholastic Sentencecommentators (1648: 14). As proved by the specific criticisms which Voetius offers against the Sentence-commentators in the rest of the disputation, he does not so much criticise scholastic method as such, but rather its exaggerated use, when it is applied to inappropriate questions or improperly used in attempts to exceed the limits of human reason (Voetius 1648: 23-24; cf. Beck 2007: 27-8). For Voetius such attempts do not constitute good examples of the sound use of scholastic method as he himself wants to practise it. It is in this latter sense that he recommended the use of scholastic method to his colleagues and students, and, in spite of all objections, the study of scholastic 
theologians from different times and confessions (1648: 27-9). Thus he studied with his students in detail medieval scholastic texts such as the Summa theologiae of Thomas Aquinas (see Beck 2013).

This understanding of scholasticism as primarily a method stands in stark contrast to Brian Armstrong's still influential definition according to which scholasticism implies a 'theological approach which asserts religious truth on the basis of deductive ratiocination from given assumptions and principles' and is 'invariably based upon an Aristotelian philosophical commitment', whereby 'reason assumes at least equal standing with faith in theology', leading to 'a pronounced interest in metaphysical matters, in abstract, speculative thought' (1969: 32). It can easily be seen that Reformed scholasticism, understood that way, would invariably be in conflict with the Reformed confessions. Instead, however, the two of them fall together in a harmonious way, as we will now demonstrate.

\section{Early Reformed Scholastics and Their Confessional Writings}

After 1560, we can observe an increasing awareness of late medieval discussions on relevant issues at the Reformed and newly founded Protestant universities and academies. It is quite significant, for instance, that the library of the Genevan Academy, founded in 1559 by John Calvin, included a great number of works by important medieval scholastic theologians such as Thomas Aquinas, Dionysius the Carthusian, Duns Scotus, and Gregory of Rimini (Ganoczy 1969: 103-8). The increasing interest in late medieval works and the use of the 'toolkit' of scholastic distinctions led to more nuance and refinement in theological doctrine, including providence and predestination, when compared to the theology of Calvin (Beck 2016). We can already observe this in the works of the Italian refugee Vermigli, who was older than Calvin, and in Calvin's successor Theodore Beza, a French refugee (Baschera 2008, 2009; Zuidema 2008; Muller 1988, 1999). Thus Beza, to focus first of all on him, not only argued that the contingency or freedom of secondary causes was not removed by the 'necessity' of the divine decree, but, in contrast with Calvin, he also endorsed the medieval concept of divine permission, albeit without opposing it to the divine decree (Beza 1670: 104-7, 112-13, 99100). Later Reformed scholastics, such as Gisbertus Voetius, would adopt the full refinements of this concept that can be found in Aquinas and Scotus: God does not have a positive act of will in relation to sin and the fall, although $\mathrm{He}$ positively wills His not having a positive act of will towards sin (Goudriaan 2006: 188-92; Beck 2007: 334-44, Beck 2011 (on Calvin and Voetius); Vos et al. 2003: 178-92).

In contrast to what much older scholarship on Beza had concluded, his use of the scholastic method did not lead to a harsher version of predestina- 
tion than that of Calvin, and surely not to a rationalistic, deductive predestinarianism, but rather enabled him to avoid undesirable implications (contra Kickel 1967; see now Mallinson 2003). Both Calvin and Beza denied that God would be the author of sin, but Beza had better tools in hand to argue that this indeed did not follow from the doctrine of predestination. Other Reformed orthodox theologians in this time such as Girolamo Zanchi, Zacharias Ursinus, and Franciscus Junius, used the same scholastic toolkit, which became only more refined in the seventeenth century (te Velde 2013: 19-43; van Asselt, Bac, et al. 2010; Wagner-Peterson 2013).

If Reformed orthodox theologians used the scholastic method for their academic work at the universities and academies, this surely does not mean that all their writings were scholastic. Especially those in the vernacular often were not. We can see this, for instance, in their confessional writings. Thus Beza's personal and quite extensive Confession de la foy chrestienne (Confession of the Christian Faith), first published in 1559 and later in many more editions, was written in typical confessional language and included several passages that expressed his pastoral concern. A striking example is the lengthy section 4:20 which he inserted in the Latin version and later French versions, in which he attempted to give a 'remedy against the last and most dangerous temptation', namely 'whether we are elect or not' (Beza 1560: 68-79, 1563: 70-80). There he encourages his readers that their salvation does not rest on their faith as such, but on Christ, whom they can trust. Referring to Matthew 17:20 he adds that 'faith is so powerful that, according to God's promise, even a single seed of faith, how small it might be, safely accepts Jesus Christ' (Beza 1560: 71-2, 1563: 73). This pastoral approach is arguably compatible with Beza's doctrine of predestination in his more scholastic texts and in his famous Tabula praedestinationis, when properly understood in its historical context (see Muller 1999; Rouwendal 2016: ch. 3).

Moving to Girolamo Zanchi (1516-1590) now, we see a similar pattern. Zanchi, an Italian refugee, was another important figure of early Reformed scholasticism who wrote a confession of faith. During his professorship at Strasbourg and later in Heidelberg and Neustadt an der Haardt, he exerted great influence on Reformed theology in the early modern period. Although he was the first to have been asked to write a Reformed counterpart to the Lutheran Formula of Concord (1577), this task was taken over by Jean-François Salvard, Beza, and Lambert Daneau, who finally compiled the Harmonia confessionum fidei (1581), a selected harmony which never achieved such significance as the Formula of Concord. Zanchi, in turn, wrote his own personal confession, De religione christiana fides, which he published in 1586 and which also appeared in Cambridge in an English translation, entitled Confession of Christian Religion (1599); both texts have been made accessible in an excellent edition by Luca Baschera and Christian Moser (Zanchi 2007). 
In contrast to Zanchi's massive volumes on the doctrine of God, which show strong Thomistic and also some Scotistic influences (Zanchi 1572, 1577; cf. Goris 2001), his confession does not belong to the genre of scholastic writings, although it can be read as a compendium of his theology and is surely more than a brief introduction of the faith to children. The confession is structured in 30 chapters and commences with a detailed discussion of Scripture as the foundation of the entire Christian religion (Zanchi 2007: 1:11229). Similar but fuller discussions of Scripture typically can be found in the prolegomena of Reformed scholastic systems, which are reminiscent of the prologues to the medieval commentaries of the Sentences of Peter Lombard.

The remaining 29 chapters follow roughly the outline of the Apostles' Creed. The most extensive chapters are devoted to 'Christ the Redeemer' (ch. 11), the 'True Dispensation of the Redemption' (ch. 12), the sacraments (ch. 14), especially the Lord's Supper and the reservations about the Lutheran doctrine of ubiquity (ch. 14), the doctrine of justification (ch. 19), the militant church (ch. 24), and the church government (ch. 25) (Zanchi 2007: $1: 198-229,230-53,265-87,299-319,335-51,389-425,425-79)$. It is telling that the two mentioned ecclesiological chapters are the most detailed by far. In contrast, the doctrine of predestination, which is discussed together with the doctrine of divine foreknowledge, receives relatively little attention (ch. $3)$. Here, Zanchi tends to what later will be called an infralapsarian position (Zanchi 2007: 1:136-46). Not all men are predestined to eternal life, but, as Zanchi adds with pastoral concern, everyone should 'stedfastlie [...] trust that, when he is called to Christ, he is called according to the eternall decree and election of God', and if he struggles with the assurance of election, he should 'not desparre, but desire of God that he will helpe his unbeleefe, hoping that he may in time be better assured' (Zanchi 2007: 1:139, 141-3).

In the likewise brief chapter on divine providence (ch. 6), Zanchi stresses that many things occur contingently with respect to secondary causes, although they are necessary with respect to God. ${ }^{1}$ Moreover, he rejects as erroneous not only 'all those philosophers, which either do wholie take awaye the providence of God out of the worlde', but also 'those which woulde have all thinges to come to passe so merely necessarily, that they take awaye all casualtie and deprive men of all libertie', and 'those which will have God so to worke all thinges in all men, that they also doe balsphemouslie prove him to bee oúvep yov a ioint-worker and an author of sinne' (Zanchi 2007: 1:1635). Consequently, Zanchi teaches in chapter eight with Augustine (1865: 899) that 'free will is always free (namely from constraint) but is not always good'.

1 Zanchi (2007: 1:156-65, esp. 156-69) does not explain whether he understands the necessity of secondary causes in respect to God in the sense Aquinas did in S.Th. I, q. 19, a. 8 , or rather in terms of Scotus's interpretation of the necessity of the consequence and its compatibility with true contingency of the consequent (see Lectura I, d. 39, n. 48, 162$65)$. 
It is important to note that, albeit Zanchi's confession clearly does not belong to the genre of technical scholastic texts, there are no signs of any tension with respect to theological content if one compares for instance chapters six and eight with sections on free choices (and providence) in two of his fullfledged scholastic treatises (1619: part 3:704-10, part 4:67-94). Indeed, the scholastic treatises arguably present with much more detail largely the same doctrine that is concisely summarized in his confession.

Zanchi had been a close colleague of Ursinus in Heidelberg and later in Neustadt an der Haardt. It is to him that we turn now, examining a third example of a Reformed scholastic who also wrote confessional texts. Apart from having written several other catechisms, Ursinus was probably the main author of the Heidelberg Catechism (1653), one of the most influential Reformed confessional writings. He ranks among the most important pupils of Philipp Melanchthon, but was also influenced by Vermigli, Bullinger, and Calvin. His lectures on the Heidelberg Catechism are reflected in the posthumously published commentary on this Catechism, which was re-issued in many versions and exerted strong influence on Reformed scholasticism (Platt 1982).

As Wagner-Peterson has argued, the doctrine of predestination became increasingly important in Ursinus' theological work during his years in Heidelberg, where he met refugees such as his colleague Girolamo Zanchi who found consolation in this doctrine (328-9). Yet the Heidelberg Catechism only alludes to predestination (Schaff 1983: 3:324-5), although it starts with the question: 'What is thy only comfort in life and in death?' (Schaff 1983: 3:307-8). Ursinus explains in his commentary on the catechism, that this question and its answer have been placed at the beginning because they entail 'the scope and sum of the whole catechism' (Ursinus 1598: 21). Apparently, the question could be answered appropriately in the catechetical context without delving into the depths of divine predestination.

At another point, also related to soteriological issues, the catechism shows more clearly influences of scholastic texts. Thus the questions and answers 11-19 of the Heidelberg Catechism, also related to soteriological issues, which partly reflect Ursinus's scholastic doctoral theses from August 1562 (1612: 1:744-53), have often been criticized for their dependence on Anselm of Canterbury's early scholastic doctrine of satisfaction. In response, some theologians tried to distance the Heidelberg Catechism as far as possible from Anselm's Cur Deus homo (e.g. Metz 1970). Yet its dependence on Anselm should neither be overstated, nor should it be downplayed (see Beck 2014). Moreover, it should not be overlooked that Anselm's thought experiment against the sceptics, even if it has been devised sola ratione and remote Christo, fell within the framework of his declared program of faith seeking understanding (fides quaerens intellectum) and presupposed that human beings were dependent on 
God for ultimate happiness, have fallen into sin, and that this affected all people. Anselm also presupposed the authority of the Catholic faith and thus especially that of Scripture (Anselm 1946: 1.10; Kienzler 1981). His point was not that God had discharged his anger in Christ because of his wounded honour; in contrast, he states that the glory of God cannot be impaired (Anselm 1946: 1.14-5; den Bok 2001; Plasger 1993). Nor did Anselm's argument depend on the medieval feudal system, since it can be detached therefrom (McIntyre 1954; Southern 1990: 221-27; van den Brink 2003). Fundamental to his argument was rather that God's justice required either punishment (poena) of the guilt of human beings, or satisfaction (satisfactio), and that God decided to do (facere) in Christ, the God-Man, precisely enough (satis) to fulfil this requirement (Anselm 1946: 1.15).

It is important to note, finally, that Anselm did not argue for a strict or absolute necessity of the incarnation, but only for a hypothetical necessity (necessitas sequens), given presuppositions such as God's compassionate, yet righteous, will to redeem human beings (Anselm 1946: 2.5, 17; Plasger 1993: 25961). Taking into account the findings of recent research on Anselm, the catechism's partial reliance on his scholastic doctrine of satisfaction is not necessarily unbiblical.

In sum, we have seen how Beza, Zanchi, and Ursinus, three proponents of early Reformed orthodoxy, contributed not only to the rise of Reformed scholasticism, but also to the diversity of Reformed confessional writings. Their confessional writings, including particular the Heidelberg Catechism, are surely not scholastic texts, although the authors made use of their scholastic and humanistic training which enabled them to place themselves in the broader catholic tradition of the Christian church. We will now zoom in on two Reformed confessions in particular, the Belgic Confession and the Canons of Dordt, in order to show from some of their various articles how their doctrinal content, though expounded in a different style, was much in line with the scholastic theology of Reformed orthodoxy and is at some points more properly understood when studied in the context of Reformed scholasticism.

\section{Scholasticism and the Belgic Confession}

The Confessio Belgica originated in the context of the persecuted "churches under the cross' in the southern Netherlands and was meant to demonstrate to the authorities that the faith of the persecuted Christians was Catholic and thus in line with the Church of the centuries (this section is partly based on Beck 2012). Guido De Brès (1522-1567), its author, had studied in Geneva, possibly under Beza, and, as is clear from one of his other works, had some interest in patristic theology (de Boer 2013). 
The first article of the Confessio Belgica has often been criticized because it includes a list of several attributes of God as it also can typically be found in scholastic systems:

We all believe with the heart, and confess with the mouth, that there is one only simple and spiritual Being, which we call God; and that he is eternal, incomprehensible, invisible, immutable, infinite, almighty, perfectly wise, just, good, and the overflowing fountain of all good (Schaff 1983: 3:383-84).

This article should not be understood as an attempt at an abstract conceptualization of the divine Being, but as an expression of faith in the context of persecution which refers to some divine attributes as they have been included through the centuries in the classical catholic doctrine of God. Thus it is striking that De Brès, obviously alluding to Romans 10:10, begins with the words: 'We all believe with the heart, and confess with the mouth', whereas the Confessio Gallicana, which is based on a draft of John Calvin and was used by De Brès, commenced with the simple phrase 'Nous croyons et confessons' (Schaff 1983: 3:383, 359).

In the next phrase, 'We believe [...] that there is one only simple and spiritual Being (essence), which we call God', De Brès seems to took over from Beza's Confession de la foy chrestienne (1559) the words 'which we call God' as Nicolaas Gootjes has shown, De Brès relied in several articles on Beza's Confession (1559: 1; 2007: 71-91, esp. 71-2). What follows is a traditional list of some divine attributes that are common to all three hypostaseis of the one divine ousia (cf. for this scholastic pattern Beck 2006: 196-97, 204-5): '[...] and that he is eternal, incomprehensible, invisible, immutable, infinite, almighty, perfectly wise, just, good, and the overflowing fountain of all good'. De Brès again comes close to the text of the Confessio Gallicana, but it is surprising that the reference to the divine potency or almightiness which is already found in the Gallicana ('qui peut toutes choses') was added to the Confessio Belgica only at a later stage. This addition was the result of a revision by the Synod of Dordt in 1619 by which, surprisingly enough, it met a request of the Remonstrants. ${ }^{2}$ The encouraging concluding phrase, 'and the overflowing fountain of all good', was also added later, that is, at the Synod of Antwerp (1566) (Gootjes 2007: 122). Thus, the original document was less 'pastoral' in tone here than we might think.

The enumeration of divine attributes in the first article follows a classic pattern and reflects the Catholic tradition of the Church Fathers and medieval theologians such as Irenaeus, Augustine, Anselm, Thomas, Bonaventura, 
and Duns Scotus. The same is true for the articles 8-11 on the three Trinitarian Persons, where De Brès refers approvingly to the creeds of the early church (Schaff 1983: 3:339-94). These articles follow those on the knowledge of God (article 2) and the doctrine of Scripture (articles 3-7).

Regarding the first article, it should be noted that according to some scholars, such as J. R. Wiskerke, the article is bent by 'the heavy burden' of 'a Greek philosophical idea of God' (1978: 93-161, esp. 122). The article would give rise to a grave misunderstanding, namely that the simplicity and spirituality of God would lead 'finally to a description of God's essence, by which God is "classified" within a single sequence which comprises both the Creator and the creatures' (Wiskerke 1978: 142). This argument seems to be based on a misunderstanding, however (cf. Gootjes 1984: 124-75, esp. 220). According to classical theology, the simplicity or simplicitas of God means precisely that God is completely different from any creature, because the term connotes that every type of complexity is excluded (Rikhof 1988: 30-32; Muller 2003b: 2:275-84). What is ruled out by the term simplicitas is not God's unicity nor his personality and vitality, but the idea that He would be composed of several entities as this is characteristic for creatures.

Thus the Reformed scholastic theologian Voetius sees an important practical use in the doctrine of the simplicity of God: It not only shows that God is unique and totally different from everything created, but it also excludes any imperfection. As such, the doctrine helps us to speak of God confidently and reverently. What is more, it brings the 'light of a lofty mysticism' and a 'pious contemplation' when we consider that there are three Persons in the one divine essence, each of whom possesses the entire essence, in mutual permeation (emperichoresis); thus, the doctrine is at odds with the antitrinitarian thoughts of the Socinians. Finally, it becomes evident how we can only think spiritually of God's essence and how 'all brute and earthly concepts' are completely insufficient, although the simplicity of God does point to His trustworthiness and that of His promises. For Voetius it is clear that 'this doctrine is not purely speculative, scholastic, metaphysical, or fruitless with respect to all confidence and every piety' (Voetius 1648: 244-45; cf. Beck 2007: 233-36).

Voetius surely did not stand alone with this interpretation, namely that attributing 'simplicity' to God does not attempt to give a definition of God. For example, also Samuel Maresius emphasised this in his commentary on the Confessio Belgica, while referring to 1 Timothy 6:16 and Psalm 8:11: 'But there is no reason why anyone would think that this first article gives an exact definition of God. For God, who is infinite and 'dwells in unapproachable light' and 'made darkness his secret place [...], cannot be precisely defined' (Maresius 1652: 16).

There has also been quite some criticism of the second article. According to Karl Barth, it is plainly absurd (Unfug) that we know God by two means as 
stated in the second article: 'first by the creation, preservation, and government of the universe', and secondly, 'by his holy and divine Word' (1940: 140-1). Barth is wary of a natural theology which would give access to God independently of Christ. In line with the Confessio Belgica, Reformed orthodoxy would have reverted, against the intent of the Reformation, to natural theology, which is independent of God's revelation. However, it is highly questionable whether Barth does justice here to the Confessio Belgica and also to Reformed scholasticism. If the Confession refers to creatures as 'characters' or letters in a 'most elegant book', 'leading us to contemplate the invisible things of God, namely his eternal power and Godhead' (Schaff 1983: 3:384, emphasis in original, corresponding with quote from Romans 1:20), this can be seen as a form of natural theology indeed. Nevertheless, natural theology in this sense is clearly not meant to distract from God's 'holy and divine Word' or to open the way to speculative theology which is independent from the divine Word. Instead, this form of natural knowledge is restricted to what is 'sufficient to convince men, and leave them without excuse', and may thereby point to the divine Word, by which 'he makes himself more clearly and fully known to us'. (Schaff 1983: 3:384; cf. van den Brink 2011; Kunz 2013). This is not different for someone like Voetius, a prominent representative of Reformed scholasticism. For him, natural theology does not constitute a 'sub-structure' for supernatural theology that must first be acquired before one can turn to actual or revealed theology (pace A. Schweizer, K. Barth, H.-E. Weber). Only for the unbeliever is there a gap between natural and supernatural theology, since natural theology falls outside the soteriological context (Beck 2007: 14974; cf. Muller 2003b: 1:270-310).

Moving to article 17 now, we can see that our interpretation of the first two articles is confirmed and that the Confessio Belgica does not endorse something like a Greek-Hellenistic conception of God as the Unmoved Mover. This important article is written in a narrative style, reflecting divine passion:

We believe that our most gracious God, in his admirable wisdom and goodness, seeing that man had thus thrown himself into temporal and spiritual death, and made himself wholly miserable, was pleased to seek and comfort him when he trembling fled from his presence, promising him that he would give his Son, who should be made of a woman, to bruise the head of the serpent, and would make him happy (Schaff 1983: 3:402).

Within the overall structure of the Confessio Belgica, this article forms the transition from the doctrine of divine election to Christology. It is useful to keep in mind the dynamics of article 17, which describes God's ways in time towards humanity, when reading article 16 on divine election in eternity (cf. Maresius 1652: 245; van Eck 1997: 16-18).

PERICHORESIS 14.3 (2016) 
Article 16, on divine election, is brief. There is no double predestination (praedestinatio gemina) to be found. Quite rightly, therefore, the orthodox Reformed theologian Festus Hommius in his Specimen controversiarum Belgicarum (1618) superscribed the article 'Of Eternal Election' with the Latin title 'De divina praedestinatione' (1618: 58). The title is aptly chosen, as it follows, in fact, the medieval pattern: predestination (praedestinatio) is synonymous with election (electio) and not a kind of double decree, which would unfold more or less symmetrically into two directions:

We believe that all the posterity of Adam, being thus fallen into perdition and ruin by the sin of our first parents, God then did manifest himself such as he is; that is to say, merciful and just: merciful, since he delivers and preserves from this perdition all whom he, in his eternal and unchangeable council, of mere goodness hath elected in Christ Jesus our Lord, without any respect to their works: just, in leaving others in the fall and perdition wherein they have involved themselves (Schaff 1983: 3:401).

The Confessio Belgica indeed identifies predestination with election: predestination refers to the 'eternal and unchangeable counsel', by which God 'of mere goodness hath elected in Christ Jesus our Lord' those to which $\mathrm{He}$ shows his mercy, i.e. the believers. Predestination thus is election in Christ by God's mercy.

There is no parallel counsel of reprobation in the Confessio Belgica; it just states that God manifested his justice by 'leaving others in the fall and perdition wherein they have involved themselves' (Schaff 1983: 3:401). Whereas election is out of mercy, and in Christ, those remaining in the fall and perdition, by their own responsibility and intention, are outside of Christ and under the just divine judgement (Maresius 1652: 241).

Thus the Confessio Belgica does not teach a version of double predestination in the sense of a strict parallelism of election and reprobation, nor does it hold to a supralapsarian position. It does entail, however, a parallelism of mercy and justice which is firmly rooted in the Western Catholic tradition. The combination of divine mercy and justice in the doctrine of predestination is not only found in Calvin and Beza, but also in Augustine, Anselm of Canterbury, Thomas Aquinas, and John Duns Scotus, to mention only a few outstanding names (cf. Maresius 1652: 239). Indeed there is little if anything at all in this article of the Belgic Confession that would be specific to the Reformed tradition. Moreover, the Confessio Belgica presents the doctrine of election in a soteriological perspective as the deeper dimension of divine grace, after the doctrine of God, revelation, Trinity, creation, and the human fall, and immediately before Christology and salvation.

In order to properly read article 16 against its historical background, we have to keep two things in mind. Firstly, the doctrine of predestination of 
Luther or Calvin had remained virtually undisputed within all churches of the Reformation until 1560. Although the interpretations of the doctrine of, say, Luther, Melanchthon, Zwingli, Bucer, Calvin, Bullinger, and Brenz differ to some extent, there were initially no inner-Protestant polemics on this doctrine. This only changed in 1560, when the 'Gnesio-Lutheran' theologian Tilemann Heshus added an epilogue titled Aliquot errores Calvini to his book, De praesentia corporis Christi in coena Domini contra Sacramentarios (Heshusius 1560: Sviijv-Tvijr; cf. Krüger 2004: 69-96; Mahlmann 1997: 125). The same book also formed the occasion for the dispute on the Lord's Supper and predestination between Zanchi and Johannes Marbach in Strasbourg (Kittelson 1977; van 't Spijker 1993). This was in 1561, the same year that the first edition of the Confessio Belgica was published.

Secondly, we have to take into account that recent research has largely disproved the highly influential claim of Schleiermacher's pupil, Alexander Schweizer, who affirmed that the doctrine of predestination formed the central dogma of Reformed orthodoxy (Schweizer 1854-1856). Calling predestination a central dogma is not only inappropriate for Reformed doctrine in the sixteenth century, but also for the seventeenth and even eighteenth centuries, although it might apply, in some sense, to the nineteenth century (Muller 2003a: 63-6, 94-100, 2003b: 1:123-32; van Asselt and Dekker 2001).

\section{The Scholastic Background of the Canons of Dordt and the Westminster Confession}

Moving now to the Canons of Dordt, part of its prehistory was determined by pastoral concerns which had come to the fore in the Low Countries as a result of the way in which the doctrine of predestination had been received (this section is partly based on Beck 2012). Around the year 1582, two Reformed ministers of Delft, Reginald Donteclock and Arent Cornelisz, claimed that the doctrine of predestination had to follow the axiom miseratio praesupponit miseriam, which means that human sin should be seen as the cause of reprobation and that one should avoid 'to ascend to the high mystery of the ultimate reason for the fall of Adam'. Thus they advocated what was later called an infralapsarian view on the object of predestination over against a supralapsarian view. In this context, Cornelisz referred to the Confessio Belgica and the Heidelberg Catechism which did not attempt 'to ascend to a higher level' (Bakhuizen van den Brink et al. 1960: 1:265-67; cf. Donteclock 1611). In 1609, however, Donteclock explained that those who still would 'ascend to a higher level' and speak of 'possible creatures' as the object of predestination rather than actual sinners, seem to differ more on the didactical sense than on the level of content. Donteclock especially thought of Franciscus Gomarus in this respect, who preferred the supralapsarian view (1609: A3a; cf. van Itterzon 1979: 156-7).

PERICHORESIS 14.3 (2016) 
Five years earlier, Gomarus had come into conflict with Jakobus Arminius on the doctrine of predestination. In order to understand the background of this conflict, we have to consider two developments taking place in the second half of the sixteenth century. The first concerns the so-called Erastian movement, which included several refugees from the Rhineland. Some ministers, such as Jan Gerritszoon Versteghe (Anastasius Veluanus), Hubrecht Duifhuis, Caspar Coolhaes, Herman Herbertsz, and Cornelis Wiggertsz, felt uneasy with article 16 of the Confessio Belgica. They were afraid that the doctrine of predestination would imply that God was the author of sin (van Oppenraaij 1906: 44-120; cf. Mahlmann 1997; van Veen and Spohnholz 2014; van Gelderen 2014).

Secondly, and even more importantly, the conflict between Arminius and Gomarus closely resembled the catholic controversies on grace in the late sixteenth century (congregatio de auxiliis gratiae). As recent research has shown, Arminius followed the position of the Jesuit theologians Luis de Molina, Petrus Fonseca, and Francisco Suárez, in basing election on God's foreknowledge of human faith by using the concept of divine middle knowledge (scientia media). Gomarus, in his reaction, came close to the response of the Dominican theologian Domingo Báñez and his supporters (Dekker 1993, 1996; Muller 1991; cf. Stanglin 2007). For Gomarus, election was not based on divine foreknowledge but on the contingent divine decree, which in his eyes left room for free and contingent human activity (see his disputation in van Asselt, Dekker, et al. 2010; cf. van Gelderen 2013).

Within the Roman Catholic Church, the doctrine of the Jesuit theologians was hotly debated and was eventually condemned by a hair's breadth. This did not happen, though, since Pope Paul V decreed in 1607 that both Jesuits and Dominicans were allowed to defend their own doctrine if only they tolerated the opposite opinion. Within the Reformed churches, however, the Synod of Dordt did produce a decision, when in 1618-1619 an international committee of dozens of delegates from all over Europe rejected the position of the Remonstrants (who followed Arminius) and their request to substantially revise the Confessio Belgica (Gootjes 2007: 133-59; cf. Goudriaan and van Lieburg 2011; Selderhuis 2015). Already in 1618, in his commentary on the Confession Festus Hommius, one of the two secretaries at the Synod, compiled a neat list of Remonstrant phrases which he judged to be at odds with the Belgic Confession (1618: 58-63).

As Donald Sinnema has argued, both parties on the Synod of Dordt had a 'different agenda': 'The Remonstrants wanted the extreme views of reprobation judged; the Synod's concern was to examine the Remonstrant idea of election based on foreseen faith' (Sinnema 1985: 447, cf. 2011). Sinnema comes to the conclusion that the Synod ultimately arrived at a 'mild rejection' of the Remonstrants' view on reprobation without anathematizing it. 
Whereas they did compile a list of errors to be rejected, it included only one explicit error related to the Remonstrant position on reprobation, or their 'denial that God's sheer will is the cause of preterition', i.e. of the passing-by of the 'others' mentioned in article 16 of the Belgic Confession (rejected error I,8) (1985: 448, 415-35). It is important to note that to say that God's will is the cause of preterition (the position of the Contra-Remonstrants) does not entail that God's will also be the cause of human sin, which is the cause of God's damnation. Sinnema rightly observed that the Synod here stood in line with Augustine, Thomas Aquinas, and 'the great Western tradition' (1985: 448).

In its Canons the Synod of Dordt indeed adopted a position on reprobation that was more moderate than the position of Calvin and even Beza. This becomes clear if one studies the judicia which give insight into an intense debate between the national and international delegates (van Asselt 2007). The Synod discussed no less than six different positions and finally adopted the 'late medieval solution' which distinguished between negative and positive reprobation (Sinnema 1985: 5, 136-40, 449). Thus, the divine will is seen 'as the cause of the negative side' (praeteritio), whereas human sin is seen 'as the cause of the positive side' (damnatio) (Sinnema 1985: 449; van Asselt 2007: 206). This entails that there is no positive divine act concerning human sin, whereas positive reprobation presupposes human sin. As the conclusio of the Canons of Dordt implies, election and reprobation are not parallel, not 'eodem modo' (Bakhuizen van den Brink 1976: 278; Schaff 1983: 3:576).

The scholastic distinction between negative and affirmative reprobation goes back to the Franciscans Nicholas de Lyra (ca. 1270-1349) and, in its definitive form, to the Scotistic theologian Étienne (Stephanus) Brulefer (died ca. 1499) who also made it popular (de Lyra 1472: ad Rom. 9:17; Brulefer 1501: ad I d. 40; cf. Sinnema 1985: 32-8). ${ }^{3}$ Brulefer related the distinction directly to John Duns Scotus's model of distinct structural moments or instances. By applying this model to predestination, Scotus could argue that divine election is not based on foreseen faith, whereas there is a relation between the divine decree and the fact that Judas finally rejected Christ and will justly be rejected in turn (see esp. Duns Scotus 1950-2013: 6.334; Vos et al. 2003: 131-164). It should be noted that Scotus's model of structural moments works with implicative relations, not with causal relations in the modern sense of the term (te Velde, Vos, et al. 2014).

Thus, if we carefully analyse the Canons of Dordt in their historical context by taking into account the scholastic background of the delegates and their debates, it becomes clear that they are not as 'rigid' as one might think 
at first sight and do not teach a version of praedestinatio gemina or double predestination in the sense of a strict parallelism of election and reprobation. Moreover, the Canons restrict themselves to the infralapsarian view on the object of predestination when they define in 1.7 election as 'the unchangeable purpose of God, whereby, before the foundation of the world, he hath [...] chosen, from the whole human race, which had fallen through their own fault [...] into sin and destruction, a certain number of persons to redemption in Christ' (Schaff 1983: 582; Bakhuizen van den Brink 1976: 232-3). Thus the Canons did not follow Gomarus on this point, who preferred the supralapsarian view. The Authentic Acts of the Synod report that, according to him, the canons should regard as the object of praedestination 'not only fallen humanity (homo lapsus), but humanity as it is considered by God before the fall'. Instead, the Synod followed the infralapsarian view of S. Lubbertus, which was supported by J. Polyander, A. Thysius, and A. Walaeus (Sinnema et al. 2015: 134, cf. 315). Later Walaeus would explain in his Loci Communes (14.5) that the infralapsarian view is 'more certain (certior) and more in agreement (convenientior) with the Word of God', although the Synod did not exclude the supralapsarian view (Walaeus 1643: 1:327). Sure enough, as Voetius argued (1669: 602-7), the infralapsarian view is fully compatible with the supralapsarian view; it is only more restricted. What the Canons did reject is the Remonstrant position that the divine election was 'founded upon foreseen faith (ex praevisa fide), and the obedience of faith, holiness, or any other good quality or disposition in man, as the prerequisite, cause, or condition on which it depended' (Schaff 1983: 583; Bakhuizen van den Brink 1976: 232-3). The Synod of Dordt clearly left room for what has been called 'lapsarian diversity' (Fesko 2011). However, they did so by using a style of teaching that is not only catholic but also popular, thus following the modus docendi of the Palatinate delegates (Godfrey 2011).

The infralapsarian view is also reflected in the Leiden Synopsis of a Purer Theology (Synopsis Purioris Theologiae, 1625), a highly influential collection of scholastic disputations that served as a dogmatic textbook at the Dutch Universities during the seventeenth century. As one of its four authors, Walaeus contributed to the Synopsis disputation 24, on divine predestination, in which he closely followed the infralapsarian definition of election of the Canons of Dordt: God 'chooses from the whole human race that had fallen by its own fault from pristine integrity into sin and destruction a specific number of individual people' (van den Belt et al. 2016: d. 24.4). He also explained the scholastic distinction between negative and affirmative reprobation, which as we saw, lay at the background of the Canons of Dordt, and concluded that negative reprobation or 'passing over' presupposes common sin, 
whereas affirmative reprobation or " "pre-damnation" in God's foreknowledge' presupposes particular sins (van den Belt et al. 2016: d. 24.4954; cf. Walaeus 1643: 2:250-1).

This viewpoint corresponds with disputation 11 on divine providence, where A. Rivetus argued that divine providence does not destroy but rather establishes human freedom. When concurring with his creatures, God through his working 'directly influences the action of the created being, so that one and the same action is said to proceed from the first and the second cause, inasmuch as one work, or the completed work, results from this source' (te Velde, van Asselt, et al. 2014: 271). Evil and sins fall indirectly under divine providence in the sense that God willingly does not prevent them from happening, without thereby approving of them, in accordance with the doctrine of divine permission (providentia permittens). Every good is ascribed to God, and every evil to created causes (276-281). As these examples demonstrate, the Leiden Synopsis presented at relevant points a scholastic elaboration of the doctrinal decisions of the Synod of Dordt.

A similar position can be found in the Westminster Confession of Faith (1646), where chapter 3.1 says of God's eternal decree:

God from all eternity did, by the most wise and holy counsel of his own will, freely and unchangeably ordain whatsoever comes to pass; yet so as thereby neither is God the author of sin, nor is violence offered to the will of the creatures, nor is the liberty or contingency of second causes taken away, but rather established (Schaff 1983: 3:608).

Accordingly, it maintains in chapter 5.2 that the immutability of the divine decree does not strictly necessitate free second causes:

Although in relation to the foreknowledge and decree of God, the first cause, all things come to pass immutably and infallibly, yet by the same providence he ordereth them to fall out, according to the nature of second causes, either necessarily, freely, or contingently (evenire necessario, libere, aut contingenter, pro natura causarum secundarum) (Schaff 1983: 3:612).

Even though this confession does not belong to the genre of scholastic writings, it strongly reflects the scholastic training of the Westminster divines (Fesko 2014: 95-124). Thus J. B. Rogers misses the point when he tries to argue that 'scholasticism' did not play any significant role in English theology before the Westminster Assembly (Rogers 1967; cf. Muller 2003a: 27).

Scholastic training is perhaps even more apparent in the Bremen Confession (Consensus Ministerii Bremensis, 1598-so much earlier than the Westminster Confession), which was prepared by Melanchthon's pupil Christoph Pezel. This confession does not only include a detailed section 'On Necessity and 
Contingeny', but also utilizes the fine scholastic distinction between the necessity of the consequence and the necessity of the consequent to explain that Scriptures such as Matthew 26:54, saying that something must happen, should not be understood in the sense of absolute necessity (necessitate absoluta), but only of the hypothetical necessity of the consequence (necessitate consequentiae) in relation to divine ordination (Müller 1903: 755-6; cf. Rohls 1987: 71-2). Interestingly, the Bremen ministers applied such scholastic distinctions precisely in favour of a comparably moderate position on the role of the divine decree.

\section{Concluding Remarks}

The Reformed confessions do not belong to the genre of scholastic writing and are not primarily meant to be used in the academic setting of the classroom at universities and academies; in this sense the relationship between Reformed confessions and scholasticism is one of diversity. Moreover, we can observe quite some diversity among both Reformed confessions and scholastic theologies themselves. Yet the confessions usually have been written by theologians who had enjoyed some academic training, and this meant in early modernity: scholastic training. Moreover, the scholastic background of these theologians enabled them to place their confessional writings in the broader catholic tradition of the Christian church and to include patristic and medieval theological insights. In this sense there is no conflict but harmony between Reformed confessions and scholasticism, nor are the confessions necessarily less 'rigid' than scholastic theology. Indeed, studying these confessions against the background of the more scholastic writings of their authors may even help to fully see the theological nuances in their articles on doctrines such as divine predestination and providence.

The confessions may be more vital for us today because they are more easily approachable and focus on what is essential for (Reformed) Christian faith, but it is important, especially for pastors and scholars, to read them in historical perspective. For this, a good understanding of Reformed scholasticism is indispensable. This alone is reason enough to study the disputations and systems of Reformed orthodoxy. In addition, it can be said without exaggeration that the Reformed scholastics have been vital within the context of their own time; they were real 'schoolmen', but many of them were pastors as well. They did impressive work to further develop Protestant theology given the specific needs of their age in the early modern period in general and the era of 'confessionalization' in particular. Since they dealt with the big questions of theology, and did so in a skillful way, drawing upon Scripture and the catholic tradition of the church by using the best tools of their time, it is still worthwhile to study their works for other reasons than purely historical ones. Of course it would be inadequate to do this in an uncritical way by 
merely repristinating their thought. After all, they themselves didn't deal in such a way with the diverse theologies of the early Reformers. Yet, with the means available in their time, they often gave surprisingly helpful and sophisticated answers to questions that are still relevant today, at least for those who embrace the (Reformed) Christian confessions. ${ }^{4}$

\section{Bibliography}

Anselm (1946) Cur Deus homo. In Schmitt FS (ed) S. Anselmi Cantuariensis archiepiscopi Opera Omnia. Edinburgh: Thomas Nelson, pp. 39-133.

Armstrong BG (1969) Calvinism and the Amyraut Heresy. Protestant Scholasticism and Humanism in Seventeenth Century France. Madison, WI: University of Wisconsin Press.

Augustine A (1865) Opera Omnia. In Patrologia Cursus Completus (Series Latina), volume 46. Paris: Imprimerie Catholique.

Bakhuizen van den Brink JN, ed (1976) De Nederlandse belijdenisgeschriften. In authentieke teksten, met inleiding en tekstvergelijkingen, second edition. Amsterdam: Ton Bolland.

Bakhuizen van den Brink JN, Dankbaar WF, Kooiman WJ, et al. (1960) Documenta Reformatoria. Teksten uit de geschiedenis van kerk en theologie in de Nederlanden sedert de hervorming. Kampen: Kok.

Barth K (1940) Kirchliche Dogmatik, volume II/1. Zollikon: Kirchlicher Verlag Zürich.

Baschera L (2008) Tugend und Rechtfertigung: Peter Martyr Vermiglis Kommentar zur Nikomachischen Ethik im Spannungsfeld von Philosophie und Theologie [Zürcher Beiträge zur Reformationsgeschichte 26]. Zürich: TVZ Theologischer Verlag Zürich.

Baschera L (2009) Aristotle and Scholasticism. In Kirby WJT, Campi E, and James FA (eds) A Companion to Peter Martyr Vermigli. Leiden/Boston: Brill, pp. 133-159.

Beck AJ (2007) Gisbertus Voetius (1589-1676). Sein Theologieverständnis und seine Gotteslehre [Forschungen zur Kirchen- und Dogmengeschichte 92]. Göttingen: Vandenhoeck \& Ruprecht.

Beck AJ (2011) 'Expositio reverentialis': Gisbertus Voetius's (1589-1676) Relationship with John Calvin. Church History and Religious Culture 91(12): 121-133.

Beck AJ (2012) Theology and Election in the Confessio Belgica. In Tomson PJ (ed) The Belgic Confession at 450. Papers read at the international symposium held in Brussels on November 27 and 28, 2011 at the occasion of the 450th anniversary of the Confessio Belgica [Analecta Bruxellensia]. Maastricht: Shaker Media, pp. 136-150. 
Beck AJ (2013) Voetius on the Subject and Formal Act of Happiness-A Scholastic Exercise. In Ballor JJ, Systema DS, and Zuidema J (eds) Church and School in Early Modern Protestantism. Studies in Honor of Richard Muller on the Maturation of a Theological Tradition [History of Christian Traditions 170]. Leiden: Brill, pp. 521-532.

Beck AJ (2014) Die Soteriologie des Heidelberger Katechismus. In Huijgen A, Fesko JV, and Siller A (eds) Handbuch Heidelberger Katechismus, Gütersloh: Gütersloher Verlagshaus, pp. 246-255.

Beck AJ (2016) God, Creation, and Providence in Post-Reformation Reformed Theology. In Lehner UL, Muller RA, and Roeber AG (eds) The Oxford Handbook of Early Modern Theology, 1600-1800 [Oxford Handbooks]. Oxford: Oxford University Press, pp. 195-212, in print.

Beza T (1559) Confession de la foy chrestienne: contenant la confirmation d'icelle, et la refutation des superstitions contraires. [Geneva]: Conrad Badius.

Beza T (1560) Confessio christianae fidei, et eiusdem collatio cum papisticis haeresibus. [Geneva]: Jean Bonnefoy.

Beza T (1563) Confession de la foy chrestienne, faite par Theodore de Besze, contenant la confirmation d'icelle, et la réfutation des superstitions contraires. Reveuë sur la latine, et augmentée, avec un abregé d'icelle. Geneva: Paul Patac.

Beza T (1670) Quaestionum et responsionum libellus, in quo praecipua Christianae

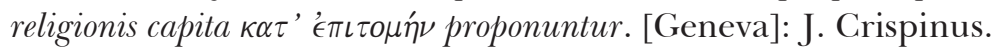

Brulefer S (1501) Clarissima in q[ua]ttuor sancti Bonaventure doctoris seraphici sente[n]tiaru[m] libros Scoti subtilis secu[n]di incipiunt feliciter. [Basel]: [s.n.].

de Boer EA (2013) Guy de Brès's 'Le baston de la foy chrestienne': from personal notebook to patristic anthology (1555-1565). Zwingliana 40(n.i.): 7399.

de Lyra N (1472) Postilla litteralis in vetus et novum testamentum, volume 5. Rome: [s.n.].

de Rijk LM (1985) La philosophie au moyen âge. Leiden: Brill.

Dekker E (1993) Rijker dan Midas: Vrijheid, genade en predestinatie in de theologie van Jacobus Arminius (1559-1609). Zoetermeer: Boekencentrum.

Dekker E (1996) Was Arminius a Molinist? Sixteenth Century Journal 27(2): 337-352.

den Bok NW (2001) Droeg hij onze straf? Over een veelbetekenend zwijgen in Anselmus' verzoeningsleer. Theologia Reformata 44(1): 5-30.

Donteclock R (1609) 'Tsamensprekinghe vande vertaelde theses ofte disputatien, de eene doct. Francisci Gomari, de andere doct. Iacobi Arminij, aenghaende de goddelicke predestinatie. [ s.1.]: [s.n.].

Donteclock R (1611) Een Grondich onderrecht wt Godts Heylighe Woort: Vande Predestinatie, of de Eeuwighe verkiesinghe Gods, in dese tyden zeer noodich [ $\mathrm{Na}$ de Kopie ghedruckt]. Leiden: Heynderick L. van Haestens. 
Duns Scotus J (1950-2013) Ioannis Duns Scoti Opera omnia. Studio et cura Commissionis Scotisticae ad fidem codicum edita, 21 volumes. Civitas Vaticana: Typis Polyglottis Vaticanis.

Ehrenpreis S and Lotz-Heumann U (2002) Reformation und konfessionelles Zeitalter [Kontroversen um die Geschichte]. Darmstadt: Wissenschaftliche Buchgesellschaft.

Fesko JV (2011) Lapsarian Diversity at the Synod of Dort. In Haykin MAG and Jones M (eds) Drawn into Controversie. Reformed Theological Diversity and Debates Within Seventeenth-Century British Puritanism [Reformed Historical Theology 17]. Göttingen: Vandenhoeck \& Ruprecht, pp. 99-123.

Fesko JV (2014) The theology of the Westminster standards. Historical context and theological insights. Wheaton, IL: Crossway.

Ganoczy A (1969) La Bibliothèque de l'Académie de Calvin. Le catalogue de 1572 et ses enseignements [Ètudes de philologie et d'histoire 13]. Genf: Librairie Droz.

Godfrey WR (2011) Popular and Catholic. The Modus Docendi of the Canons of Dordt. In Goudriaan A and van Lieburg FA (eds) Revisiting the Synod of Dordt (1618-1619) [Brill's Series in Church History 49]. Leiden: Brill, pp. 243-260

Gootjes NH (1984) De geestelijkheid van God. Franeker: Wever.

Gootjes NH (2007) The Belgic Confession. Its History and Sources. Grand Rapids, MI: Baker Academic.

Goris H (2001) Thomism in Zanchi's Doctrine of God. In van Asselt WJ and Dekker E (eds) Reformation and Scholasticism. An Ecumenical enterprise [Texts and Studies in Reformation and Post-Reformation Thought]. Grand Rapids, MI: Baker Academic, pp. 121-139.

Goudriaan A (2006) Reformed Orthodoxy and Philosophy, 1625-1750. Gisbertus Voetius, Petrus van Mastricht, and Anthonius Driessen [Brill's Series in Church History 26]. Leiden: Brill.

Goudriaan A and van Lieburg FA, eds (2011) Revisiting the Synod of Dort (16181619) [Brill's Series in Church History]. Leiden: Brill.

Heshusius T (1560) De praesentia corporis Christi in Coena Domini contra sacramentarios. Jena: Donatus Ritzenhain.

Hommius F (1618) Specimen controversiarum Belgicarum, seu, Confessio ecclesiarum Reformatarum in Belgio: cujus singulis articulis subjuncti sunt articuli discrepantes. Leiden: Ex Officina Elzeviriana.

Kickel W (1967) Vernunft und Offenbarung bei Theodor Beza. Zum Problem des Verhältnisses von Theologie, Philosophie und Staat [Beiträge zur Geschichte und Lehre der Reformierten Kirche 25]. Neukirchen-Vluyn: Neukirchener Verlag.

Kienzler K (1981) Glauben und Denken bei Anselm von Canterbury. Freiburg im Breisgau: Herder.

PERICHORESIS 14.3 (2016) 
Kittelson J (1977) Marbach vs. Zanchi. The Resolution of Controversy in Later Reformation Strasbourg. Sixteenth Century Journal 8(3): 31-44.

Krüger T (2004) Empfangene Allmacht. Die Christologie Tilemann Heshusens (1527-1588) [Forschungen zur Kirchen- und Dogmengeschichte 87]. Göttingen: Vandenhoeck \& Ruprecht.

Kunz AJ (2013) Als een prachtig boek. Nederlandse Geloofsbelijdenis artikel 2 in de context van de vroegreformatorische theologie. Zoetermeer: Boekencentrum.

Kuyper HH (1899) De Post-acta of nahandelingen van de Nationale Synode van Dordrecht in 1618 en 1619 gehouden. Amsterdam: Höveker \& Wormser.

Mahlmann T (1997) Prädestination V: Reformation bis Neuzeit. In Müller G (ed) Theologische Realenzyklopädie. Berlin: De Gruyter, pp. 118-156.

Mallinson J (2003) Faith, Reason, and Revelation in Theodore Beza, 1519-1605. Oxford: Oxford University Press.

Maresius S (1652) Foederatum Belgium orthodoxum; sive confessionis ecclesiarum Belgicarum exegesis, qua illius veritas ex Dei verbo et antiquitate catholica asseritur, et adversus oppositos errores vindicatur. Groningen: Apud Joannem Nicolaum.

McIntyre J (1954) St. Anselm and his Critics. A Re-Interpretation of the Cur Deus homo. Edinburgh: Oliver and Boyd.

Metz W (1970) Necessitas satisfactionis? Eine systematische Studie zu den Fragen 12-18 des Heidelberger Katechismus und zur Theologie des Zacharias Ursinus. Zürich: Zwingli Verlag.

Müller EFK, ed (1903) Die Bekenntnisschriften der Reformierten Kirche. In authentischen Texten mit geschichtlicher Einleitung und Register. Leipzig: A. Deichert.

Muller RA (1988) Christ and the Decree: Christology and Predestination in Reformed Theology from Calvin to Perkins [Studies in Historical Theology 2]. Grand Rapids, MI: Baker.

Muller RA (1991) God, Creation, and Providence in the Thought of Jacob Arminius. Sources and Directions of Scholastic Protestantism in the Era of Early Orthodoxy. Grand Rapids, MI: Baker.

Muller RA (1999) The use and abuse of a document: Beza's Tabula praedestinationis, the Bolsec Controversy, and the Origins of Reformed orthodoxy. In Trueman CR and Clark RS (eds) Protestant Scholasticism. Essays in Reassessment. Carlisle: Paternoster, pp. 33-61.

Muller RA (2003a) After Calvin. Studies in the Development of a Theological Tradition [Oxford Studies in Historical Theology]. New York, NY: Oxford University Press.

Muller RA (2003b) Post-Reformation Reformed Dogmatics. The Rise and Development of Reformed Orthodoxy, ca. 1520 to ca. 1725, 4 volumes, second edition. Grand Rapids, MI: Baker.

Muller RA (2011) Diversity in the Reformed Tradition. A Historiographical Introduction. In Haykin MAG and Jones M (eds) Drawn into Controversie. 
Reformed Theological Diversity and Debates Within Seventeenth-Century British Puritanism [Reformed Historical Theology 17]. Göttingen: Vandenhoeck \& Ruprecht, pp. 11-30.

Perreiah AR (2014) Renaissance Truths. Humanism, Scholasticism and the Search for the Perfect Language. Surrey: Ashgate.

Plasger G (1993) Die Not-Wendigkeit der Gerechtigkeit. Eine Interpretation zu 'Cur Deus homo' von Anselm von Canterbury [Beiträge zur Geschichte der Philosophie und Theologie des Mittelalters 38]. Münster: Aschendorff.

Platt JE (1982) Reformed Thought and Scholasticism. The Arguments for the Existence of God in Dutch Theology, 1575-1650 [Studies in the History of Christian Thought 29]. Leiden: Brill.

Rikhof HWM, ed (1988) Over God spreken. Een tekst van Thomas van Aquino uit de Summa Theologiae (I, Q. 13) [Sleutelteksten in godsdienst en theologie 6]. Delft: Meinema.

Rogers JB (1967) Scripture in the Westminster Confession. A Problem of Historical Interpretation for American Presbyterianism. Grand Rapids, MI: Eerdmans.

Rohls J (1987) Theologie reformierter Bekenntnisschriften. Von Zürich bis Barmen. Göttingen: Vandenhoeck \& Ruprecht.

Rouwendal PL (2016) Predestination and Preaching in Genevan Theology from Calvin to Pictet. Kampen: Summum Academic Publishing, in print.

Schaff P (1983) The Creeds of Christendom. With a History and Critical Notes, 3 volumes, sixth edition 1931; reprinted. Grand Rapids, MI: Baker Book House.

Schilling H, ed (1986) Die reformierte Konfessionalisierung in Deutschland. Das Problem der Zweiten Reformation [Schriften des Vereins für Reformationsgeschichte 195]. Gütersloh: Gütersloher Verlagshaus Mohn.

Schweizer A (1854-56) Die protestantischen Centraldogmen in ihrer Entwicklung innerhalb der reformierten Kirche, 2 volumes. Zürich: Orell, Fuessli, und Comp.

Selderhuis HJ (2015) Introduction to the Synod of Dordt (1618-1619). In Sinnema DW, Moser C, and Selderhuis HJ (eds) Acta et documenta Synodi Nationalis Dordrechtanae (1618-1619), pp. xv-xxxii.

Selderhuis HJ and Wriedt M, eds (2006) Bildung und Konfession. Theologenausbildung im Zeitalter der Konfessionalisierung [Spätmittelalter und Reformation, Neue Reihe 27]. Tübingen: Mohr Siebeck.

Sinnema DW (1985) The Issue of Reprobation at the Synod of Dort (1618$19)$ in the Light of the History of This Doctrine. PhD Dissertation, Toronto: University of St. Michael's College.

Sinnema DW (1999) The Distinction between Scholastic and Popular. Andreas Hyperius and Reformed Scholasticism. In Trueman CR and Clark RS (eds) Protestant Scholasticism. Essays in Reassessment. Carlisle: Paternoster, pp. 127-143.

PERICHORESIS 14.3 (2016) 
Sinnema DW (2011) Calvin and the Canons of Dordt (1619). Church History and Religious Culture 91(1-2): 87-103.

Sinnema DW, Moser C, and Selderhuis HJ, eds (2015) Acta of the Synod of Dordt [Acta et documenta Synodi Nationalis Dordrechtanae (1618-1619) 1]. Göttingen: Vandenhoeck \& Ruprecht.

Southern RW (1990) Saint Anselm. A Portrait in a Landscape. Cambridge: Cambridge University Press.

Stanglin KD (2007) Arminius on the Assurance of Salvation. The Context, Roots, and Shape of the Leiden Debate, 1603-1609 [Brill's Series in Church History 27]. Leiden: Brill.

te Velde D (2013) The Doctrine of God in Reformed Orthodoxy, Karl Barth, and the Utrecht School. A Study in Method and Content [Studies in Reformed Theology 25]. Leiden: Brill.

te Velde D, van Asselt WJ, Faber A, and den Boer W, eds (2014) Synopsis purioris theologiae $=$ Synopsis of a purer theology. Latin Text and English Translation: Volume 1, Disputations 1-23 [Studies in Medieval and Reformation Traditions 187]. Leiden: Brill.

te Velde D, Vos A, Veldhuis H, et al. (2014) Verkiezing en verwerping bij Johannes Duns Scotus. Een analyse van Ordinatio I 41. Kerk en Theologie 65(3): 233-248.

Ursinus Z (1598) Explicationum Catecheticarum D. Zachariae Ursini Silesii absolutum opus: totiusque Theologiae purioris quasinovum corpus. Pareus D (ed). Neustadt a.d. Hardt: Harnisius.

Ursinus Z (1612) Opera theologica, 3 volumes. Heidelberg: Lancelot.

van Asselt WJ (2007) No Dordt Without Scholasticism. Willem Verboom on the Canons of Dordt. Church History and Religious Culture 87(2): 203-210.

van Asselt WJ (2011) Introduction to Reformed Scholasticism. Grand Rapids, MI: Reformation Heritage Books.

van Asselt WJ (2013) Reformed Orthodoxy: A Short History of Research. In Selderhuis HJ (ed) A Companion to Reformed Orthodoxy [Brill's Companions to the Christian Tradition]. Leiden: Brill, pp. 11-26.

van Asselt WJ and Dekker E (2001) Introduction. In van Asselt WJ and Dekker E (eds) Reformation and Scholasticism. An Ecumenical enterprise [Texts and Studies in Reformation and Post-Reformation Thought]. Grand Rapids, MI: Baker Academic, pp. 11-43.

van Asselt WJ, Bac JM, and te Velde RT, eds (2010) Reformed Thought on Freedom. The Concept of Free Choice in the History of Early-Modern Reformed Theology [Texts and Studies in Reformation \& Post-Reformation Thought]. Grand Rapids, MI: Baker Academic.

van Asselt WJ, Dekker E, and Schouten MA (2010) Undisputed Freedom. A Disputation of Franciscus Gomarus (1563-1641). In van Asselt WJ, Bac M, and te Velde D (eds) Reformed Thought on Freedom. The Concept of Free Choice 
in the History of Early-Modern Reformed Theology [Texts and Studies in Reformation and Post-Reformation Thought]. Grand Rapids: Baker Academic, pp. 127-144.

van den Belt H, Beck AJ, Faber A, and den Boer W, eds (2016) Synopsis purioris theologiae $=$ Synopsis of a purer theology. Latin Text and English Translation: Volume 2, Disputations 24-42 [Studies in Medieval and Reformation Traditions 204]. Leiden: Brill, in print.

van den Brink G (2003) Verzoening als motief voor de menswording bij Anselmus en in de Heidelbergse Catechismus. In Bok N den and Labooy G (eds) Wat God bewoog mens te worden. Gedachten over de incarnatie. Zoetermeer: Boekencentrum, pp. 94-114.

van den Brink G (2011) A Most Elegant Book. The Natural World in Article 2 of the Belgic Confession. Westminster Theological Journal 73(2): 273-292.

van Eck J (1997) En toch beweegt Hij. Over de godsleer in de Nederlandse belijdenisgeschriften. Franeker: Van Wijnen.

van Gelderen M (2013) Arminian Trouble. Calvinist Debates on Freedom. In Skinner Q and van Gelderen M (eds) Freedom and the Construction of Europe. Volume 1: Religious and Constitutional Liberties. Cambridge: Cambridge University Press, pp. 21-37.

van Gelderen M (2014) Hot Protestants. Predestination, the Freedom of the Will, and the Making of the Modern European Mind. In van den Brink G and Höpfl HM (eds) Calvinism and the Making of the European Mind [Studies in Reformed Theology 27]. Leiden: Brill, pp. 131-154.

van Itterzon GP (1979) Franciscus Gomarus. Groningen/Castricum: Bouma's Boekhuis.

van Oppenraaij T (1906) La doctrine de la prédestination dans l'église réformée des Pays-Bas depuis l'origine jusqu'au synode national de Dordrecht en 1618 et 1619. Etude historique. Dissertationes ad gradum doctoris in Facultate Theologica consequendum. Louvain: J. van Linthout.

van 't Spijker W (1993) Bucer als Zeuge Zanchis im Straßburger Prädestinationsstreit. In Oberman $\mathrm{HO}$ et al. (eds) Reformiertes Erbe. Festschrift für Gottfried W. Locher zu seinem 80. Geburtstag. Zwingliana 19(2): n.p. Zürich: Theologischer Verlag Zürich, pp. 327-342.

van Veen MGK and Spohnholz J (2014) Calvinists vs. Libertines. A New Look at Religious Exile and the Origins of the 'Dutch' Tolerance. In van den Brink G and Höpfl HM (eds) Calvinism and the Making of the European Mind [Studies in Reformed Theology 27]. Leiden: Brill, pp. 76-99.

Voetius G (1648) Selectae disputationes theologicae, volume 1. Utrecht: Joannes à Waesberge.

Voetius G (1663) Politica ecclesiastica. Amsterdam: Joannes à Waesberge. Voetius G (1669) Selectae disputationes, volume 5. Utrecht: Ant. Smytegelt. 
Vos A (2013) Reformed Orthodoxy in the Netherlands. In Selderhuis HJ (ed) A Companion to Reformed Orthodoxy [Brill's Companions to the Christian tradition]. Leiden: Brill, pp. 121-176.

Vos A, Veldhuis H, Dekker E, et al., eds (2003) Duns Scotus on Divine Love. Texts and Commentary on Goodness and Freedom, God, and Humans. Aldershot: Ashgate.

Wagner-Peterson B (2013) Doctrina schola vitae. Zacharias Ursinus (1534-1583) als Schriftausleger [Refo500 Academic Studies]. Göttingen: Vandenhoeck \& Ruprecht.

Walaeus A (1643) Opera omnia, 2 volumes. Leiden: Franciscus Hackius.

Wiskerke JR (1978) De Geestelijkheid van God. In De strijd om de sleutel der kennis: Een bundel opstellen over theologie en filosofie. Groningen: De Vuurbaak, pp. 93-161.

Zanchi G (1572) De tribus Elohim, aeterno Patre, Filio, et Spiritu Sancto, uno eodemque Iehova. [s.l.]: [s.n].

Zanchi G (1577) De natura Dei seu De divinis attributis, libri V. Heidelberg: [Jacobus Mylius].

Zanchi G (1619) Omnia opera theologica, volume 2. Geneva: Samuel Crispin.

Zanchi G (2007) De religione Christiana fides_Confession of Christian religion, 2 volumes [Baschera L and Moser C (eds), Studies in the History of Christian Traditions 135]. Leiden: Brill.

Zuidema J (2008) Peter Martyr Vermigli (1499-1562) and the Outward Instruments of Divine Grace [Reformed Historical Theology 4]. Göttingen: Vandenhoeck \& Ruprecht. 